\title{
A Study of Debt Structure Preference Based on Controlling Shareholders' Benefits of Control
}

\author{
Yanhui Wang, Yajun Guo \& Xueting Song \\ School of Business Administration, Northeastern University \\ Shenyang 110004, China \\ E-mail: hhlong229@sina.com.cn
}

\begin{abstract}
Taking data of all A-share listed companies in Shanghai Stock Exchange and Shenzhen Stock Exchange from 2002 to 2006 as samples, this paper makes an empirical study on the debt structure preference of enterprises in which controlling shareholders have the right of control. Results show that these enterprises: (1) prefer to short-term debt financing concerning the debt maturity structure; (2) prefer to financing by loaning from banks concerning the debt type structure; (3) prefer to high-priority debt structure concerning the debt priority.
\end{abstract}

Keywords: Debt structure preference, Benefits of control, Controlling shareholder, Creditor

Former studies of domestic and foreign scholars show that the debt structure is affected by many factors, including corporate scale, debt scale, assets maturity, growth, and investment chance (Barclay.M.J, \& Smith.Jr, 1995, p609-631; Guedes. J, \& T. Opler, 1996, p. 1809-1833). In perspective of corporate governance, it is mainly affected by managerial stock ownership and stock right structure. Fama (1980) supplies proofs for the opinion of "the more effective the board is, the more short-term debts, the managerial level chooses". He points out that short-term debt is a powerful tool for supervising the managerial level. Besides, short-term debt gives creditors the flexibility of supervising the managerial level effectively by small efforts (Fama,E. F., 1980, p. 288-307). Datta et al (2005) verifies the effects of managerial stock ownership on enterprises choosing the debt maturity structure. Researches show that there is a negative correlation between the proportion of managerial stock owership and the debt maturity (Datta S, Datta A I \& Raman K., p. 2333-2350). Xingquan Yang and Huimin Song (2006) agree that because enterprises with concentrated stock right can control the managerial level effectively, they choose less long-term debts than enterprises with separate stock right (Xingquan Yang \& Huimin Song, 2006, p13-16). Recently in China, the influences of the right of control over the debt financing start to gain more attentions. Shuzhen Mao (2008), based on the institutional background of Chinese government interference, studies the relationship between the motivation of the ultimate control person pursuing for private interests from the control right and the debt maturity structure of listed company. Results show that the stronger the motivation is, the higher the enterprise's short-term debt ratio (Shuzhen Mao, 2008). This paper tries to study the effects of controlling shareholders on enterprises' preference for debt maturity structure, debt type structure, and debt priority structure in order to further probe into the relationship of corporate governance and debt structure.

\section{Theoretical analysis}

The right of control can be realized by indirect control. Under the "one-share one-vote" principle, the right of control rises along with the increase of ownership. Therefore, the right of control is in the hand of controlling shareholders. To master the right of control is inevitably accompanied with benefits of control. The benefits of control are not from investment, which are the total excessive profits obtained by subjects who master right of control over an enterprise. As rational men, controlling shareholders will choose the debt structure that benefits themselves a lot in order to obtaining the maximum benefits of control.

Controlling shareholders' benefits of control are mainly realized by these means: Occupy enterprises' capitals by related transactions, take listed companies' assets that are more than loans as guaranty or mortgage, and sell products to enterprises at higher prices or buy products from enterprises at lower prices. All these can make the transaction price straying from the reasonable price to a great degree, which will benefit the controlling shareholders a lot. Therefore, in perspective of debt structure, enterprises with controlling shareholders prefer to choose short-term debts that supervise and restrict less on corporate related transactions and guaranties. As for choosing the debt maturity structure, more 
restrictions concern long-term debts. Therefore, enterprises with controlling shareholders prefer to short-term debts. Concerning the choice of debt type structure, more complicated procedures are needed for issuing bonds. And the examinations and requirements for enterprises are higher. So, enterprises with controlling shareholders prefer to apply loans from banks. In perspective of debt priority structure, the higher the debt priority grade, the more the creditors' interests can be guaranteed. Then, the supervision on enterprises will become weak and controlling shareholders take the assets that are more than listed companies' loan scales as guaranties or mortgages. Therefore, enterprises with controlling shareholders prefer to the debt with higher priority grade.

\section{Design an empirical study}

\subsection{Sample selection and data sources}

In China most listed companies are reformed from state-owned enterprises. The rights of control of state-owned enterprises are completely in the hand of managerial level. Contrarily, in non-state-owned listed companies, for enterprises with relatively concentrative stock right, because of the information asymmetry derived from the imperfect of regulatory and supervision system, the controlling shareholders and the managerial level control the information that is out of the hand of more small and medium-sized shareholders and creditors. Non-state-owned enterprises may also face the problems of managerial level obtaining benefits of control. But compared with controlling shareholders obtaining benefits of control, these benefits of control tend to be less important because the right of control is mainly in the hand of controlling shareholders. In this paper, the non-state-owned listed companies with relatively concentrative stock right is sorted into the enterprises in which controlling shareholders control.

All data are from the CSMAR database, CCER Chinese financial database, and Resset database supplied by Guotaian Research Service Center. Some are processed manually based on the annual reports of listed companies in Shenzhen Stock Exchange and Shanghai Stock Exchange. This paper makes selection from samples: (1) delete banking financial listed companies; (2) delete companies whose annual auditing reports at the current year are non-standard and unpreserved opinions; (4) delete the listed companies that are listed at the current year; (5) delete companies with incomplete data.

\subsection{Select variables}

This paper adopts the common linear regression model for testing the causation relationship of variables. Furthermore, because the empirical study concerns many independent variables and dependent variables, we choose the PLS2 regression model that is for multiple variables for multiple variables.

(1) Explained variables (dependent variables)

Because the debt structure can be sorted into three types, as we set up a regression model of debt structure and make an empirical study based on the benefits of control, we need three regression models. Therefore, three types of explained variables are necessary.

a. Debt maturity structure: Debts can be classified into short-term debts and long-term debts. Use the short-term debts ratio to represent the debt maturity structure, namely short-term debts/total debts, SD.

b. Debt type structure: three types according to the sources of debts

Loans from banks: proportion of short-term debts, one-year long-term debts, and long-term debts to total debts (YHJK)

Commercial credit: proportion of business payable and funds received in advance to total debts (SYXY)

Bond: proportion of bonds payable to total debts (ZQ)

c. Debt priority structure: four types according to the priority of payment

Pledge and mortgage debt: proportion of pledge loans and mortgage loans to total debts (ZDY)

Guaranty debt: proportion of guaranty debts to total debts (BZZW)

Credit debt: proportion of credit debts to total debts (XYZW)

Other debts: proportion of other debts except pledge and mortgage debt, guaranty debt, and credit debt to total debts (QTZW)

(2) Explanatory variables (independent variables)

In studying the debt structure based on controlling shareholders' benefits of control, the benefits mainly include: to occupy listed companies' funds, to make listed companies to supply guaranties for debts, and to perform related transactions with listed companies. So, we take the three aspects as explanatory variables.

a. Benefits from occupying funds: to divide the net assets by the sum of the occupied funds, including business funds and non-business funds, occupied by the controlling shareholders and their related parties, namely zjzy

b. Benefits from guaranteeing from debts: to divide the net assets by the sum of guaranties offered by listed companies 
for the controlling shareholders and the related parties, namely zwdb

c. Benefits from related transactions: to divide the total operating income by the income from related transactions with listed companies, namely glsy

(3) Control variables

Because enterprises' debt structure is under the influences of assets maturity, corporate scales, and debts scales and these influences can not be reflected by the benefits from control, here we take other main factors that may influence the debt structure as control variables. In specific, these variables are shown in Table 2 as follow.

\subsection{Analyze the empirical results}

The regression results of effects of listed companies' controlling shareholders' benefits of control on debt maturity structure, type structure, and priority structure are shown in Table 3, 4, and 5 as follow.

From the regression results in Table 3, controlling shareholders' benefits of control have a positive correlation with debt maturity structure, which means the stronger the motivation for controlling shareholders pursuing for benefits of control (the higher the benefits of control), the higher the ratio of listed companies' short-term debts. Therein, the positive correlation between the benefits from occupying funds and the debt maturity structure is the most significant (Sig. $=$ 0.003 , be significant under the 0.01 level). Then, the positive correlation between the benefits from related transactions and the debt maturity structure is stronger. And last the positive correlation between the benefits from guaranties and the debt maturity structure is weakest.

From the regression results in Table 4, the benefits of control obtained by controlling shareholders have a significant positive correlation with bank loans (be significant under the 0.01 and 0.05 level respectively). Controlling shareholders' benefits of control have no significant impacts on bonds.

According to the regression results in Table 5, among the benefits of control obtained by controlling shareholders, there is a significant positive correlation between benefits from guaranteeing for debts and pledge and mortgage debts, and so does between benefits from occupying funds and related transactions and guaranty debts (be significant under 0.01 level). Besides, related transactions exert effects on other debts' priority structure. In other words, there is a relatively significant negative correlation between related transactions and credit debt (be significant under 0.01 level). There is a positive correlation between related transactions and pledge and mortgage debts. The negative correlation between related transactions and other debts is not significant. It means that there is a significant correlation between controlling shareholders' motivation of obtaining benefits by occupying listed companies' funds and guaranty debt. The motivation of obtaining benefits from guaranteeing for debts gives a priority to the pledge and mortgage debt in debt priority structure. The motivation of obtaining benefits from the related transactions makes controlling shareholders prefer to guaranty debt rather then credit debt. The motivation of obtaining benefits from related transactions has certain effects on controlling shareholders choosing the pledge and mortgage debt and the credit debt. But the effects are not significant.

\section{Conclusion}

(1) Concerning the debt maturity structure, controlling shareholders prefer to short-term debts in order to obtain more benefits of control.

(2) Concerning the debt type structure, controlling shareholders prefer to applying loans from banks to certain degree. For listed companies with controlling shareholders, the debt type structure fluctuates dramatically during the sample term, what may be caused by the incomplete data of samples,

(3) Concerning the debt priority structure, controlling shareholders' behaviors are clearer. They prefer to debts with higher priorities rather than that with lower priorities.

\section{References}

Barclay.M.J, \& Smith.Jr. (1995). The maturity structure of corporate debt. Journal of Finance, No. 50, p. 609-631.

Fama,E. F. (1980). Agency problems and the theory of the firm. Journal of Political Economy, No. 88, p.288-307.

Guedes.J, \& T. Opler. (1996). The determinants of the maturity of corporate debt issues. Journal of Finance, No.51, p.1809-1833.

Mao, Shuzhen. (1008). The ultimate control over personal income and listed companies' debt maturity structure. [Online] Available: www.baf.cuhk.edu.hk

Yang, Xingquan. (2006). An empirical study on the influencing factors of China listed companies' debt maturity structure. Modernization of management, No.1, p.13-16. 
Table 1. Yearly distribution of sample enterprises with controlling shareholders.

\begin{tabular}{l|lccccc}
\hline Year & 2002 & 2003 & 2004 & 2005 & 2006 & Total \\
\hline $\begin{array}{l}\text { Number } \\
\text { samples }\end{array}$ & 91 & 105 & 13 & 139 & 150 & 498 \\
\hline
\end{tabular}

Table 2. Name of variable and index calculation

\begin{tabular}{|c|c|c|c|c|}
\hline Variable & \multicolumn{2}{|c|}{ Name of variable } & Signal & Variable description \\
\hline \multirow{8}{*}{$\begin{array}{l}\text { Explained } \\
\text { variables }\end{array}$} & $\begin{array}{l}\text { Debt maturity } \\
\text { structure }\end{array}$ & $\begin{array}{l}\text { Ratio of } \\
\text { short-term } \\
\text { debts }\end{array}$ & SD & Short-term debts / Total debts \\
\hline & & $\begin{array}{l}\text { Loans from } \\
\text { banks }\end{array}$ & YHJK & $\begin{array}{l}\text { (Short-term debt }+ \text { long-term debt }) / \text { Total } \\
\text { debts }\end{array}$ \\
\hline & $\begin{array}{ll}\text { Debt type } \\
\text { structure }\end{array}$ & $\begin{array}{l}\text { Commercial } \\
\text { credit }\end{array}$ & SYXY & $\begin{array}{l}\text { (Business funds payable }+ \text { funds received } \\
\text { in advance }) / \text { Total debts }\end{array}$ \\
\hline & & Bond & ZQ & Bonds payable / Total debts \\
\hline & & $\begin{array}{l}\text { Pledge and } \\
\text { mortgage } \\
\text { debts }\end{array}$ & ZDY & $\begin{array}{l}\text { (Pledge debt }+ \text { mortgage debt }) / \text { Total } \\
\text { debts }\end{array}$ \\
\hline & $\begin{array}{l}\text { Debt priority } \\
\text { structure }\end{array}$ & $\begin{array}{l}\text { Guaranty } \\
\text { debt }\end{array}$ & BZZW & Guaranty debt / Total debts \\
\hline & & Credit debt & XYZW & Credit debt / Total debts \\
\hline & & Other debts & QTZW & Other debts / Total debts \\
\hline & Controlling & $\begin{array}{l}\text { Funds } \\
\text { occupation }\end{array}$ & ZJZY & $\begin{array}{l}\text { The sum of funds occupied by controlling } \\
\text { shareholders and related parties / Net } \\
\text { assets }\end{array}$ \\
\hline $\begin{array}{l}\text { Explanatory } \\
\text { variables }\end{array}$ & $\begin{array}{l}\text { shareholders' } \\
\text { benefits of }\end{array}$ & $\begin{array}{l}\text { Guaranty for } \\
\text { debt }\end{array}$ & ZWDB & $\begin{array}{l}\text { Guaranties for controlling shareholders } \\
\text { and related parties / Net assets }\end{array}$ \\
\hline & control & $\begin{array}{l}\text { Benefits } \\
\text { from related } \\
\text { transactions }\end{array}$ & GLSY & $\begin{array}{l}\text { Total income from related transactions / } \\
\text { Total operational income }\end{array}$ \\
\hline Control & Assets maturity & & $\mathrm{AM}$ & Current assets / Total assets \\
\hline & Corporate scale & & SIZE & Total assets' natural logarithm \\
\hline & Debt scale & & DB & Total liabilities / Total assets \\
\hline
\end{tabular}

Table 3. The regression results of debt maturity structure based on controlling shareholders' benefits of control.

\begin{tabular}{|l|l|l|l|l|l|}
\hline & $\mathrm{B}$ & Std. Error & $\mathrm{t}$ & Sig. & VIF \\
\hline $\begin{array}{l}\text { Benefits from } \\
\text { occupying funds }\end{array}$ & .060 & .020 & 2.987 & .003 & 1.068 \\
\hline $\begin{array}{l}\text { Benefits from debt } \\
\text { guaranty }\end{array}$ & .091 & .052 & 1.733 & .084 & 1.062 \\
\hline $\begin{array}{l}\text { Benefits from related } \\
\text { transactions }\end{array}$ & .021 & .010 & 2.058 & .040 & 1.043 \\
\hline Assets maturity & .190 & .026 & 7.193 & .000 & 1.023 \\
\hline Corporate scale & .031 & .006 & 5.076 & .000 & .000 \\
\hline Debt scale & .486 & .023 & 21.305 & 1.020 \\
\hline R Squared =.565 (Adjusted R Squared $=.560) ; \mathrm{F}=106.237, \mathrm{p}=0.000$ & 1.058 \\
\hline
\end{tabular}


Table 4. The regression results of debt type structure based on controlling shareholders' benefits of control.

\begin{tabular}{|l|l|l|l|l|l|l|}
\hline & \multicolumn{2}{|l|}{ Loans from banks } & \multicolumn{2}{l|}{ Commercial credit } & \multicolumn{2}{l|}{ bond } \\
\cline { 2 - 7 } & $\mathrm{B}$ & $\mathrm{t}$ & $\mathrm{B}$ & $\mathrm{t}$ & $\mathrm{B}$ & $\mathrm{t}$ \\
\hline $\begin{array}{l}\text { Benefits from } \\
\text { occupying } \\
\text { funds }\end{array}$ & $.044^{* *}$ & 2.225 & -.001 & -.075 & -.001 & -.295 \\
\hline $\begin{array}{l}\text { Benefits from } \\
\text { debt guaranty }\end{array}$ & $.109^{* *}$ & 2.124 & -.033 & -.722 & -.004 & -.407 \\
\hline $\begin{array}{l}\text { Benefits from } \\
\text { related } \\
\text { transactions }\end{array}$ & $.035^{* * *}$ & 3.512 & -.012 & -1.333 & .000 & -.342 \\
\hline Assets maturity & $-.100^{* * *}$ & -3.826 & $.214^{* * *}$ & 9.200 & -.004 & -.874 \\
\hline Corporate scale & $.033^{* * *}$ & 5.450 & $.013^{* *}$ & 2.529 & $.003 * * *$ & 2.629 \\
\hline Debt scale & $.349^{* * *}$ & 15.634 & $.242^{* * *}$ & 12.257 & .001 & .203 \\
\hline Adjusted R2 & .433 & .341 & .004 & 1.278 \\
\hline F & $55.270^{* * *}$ & $37.778^{* * *}$ & 498 \\
\hline Sample & 498 & 498 & & \\
\hline$* * * * *$ and $*$ means being statistical significant under the $0.01,0.05$, and 0.1 level respectively (2-tailed). \\
\hline
\end{tabular}

Table 5. The regression results of debt priority structure based on controlling shareholders' benefits of control.

\begin{tabular}{|c|c|c|c|c|c|c|c|c|}
\hline & $\begin{array}{l}\text { Pledge a } \\
\text { debt }\end{array}$ & d mortgag & Guaranty & & Credit de & & Other de & \\
\hline & B & $\mathrm{t}$ & B & $t$ & B & $t$ & B & $t$ \\
\hline $\begin{array}{l}\text { Benefits from } \\
\text { occupying funds }\end{array}$ & -.003 & -.145 & $.057 * * *$ & 3.022 & -.003 & -.282 & -.011 & -.566 \\
\hline $\begin{array}{l}\text { Benefits from debt } \\
\text { guaranty }\end{array}$ & $.153 * * *$ & 3.207 & -.020 & -.409 & -.008 & -.332 & -.052 & -1.074 \\
\hline $\begin{array}{l}\text { Benefits from related } \\
\text { transactions }\end{array}$ & $\mathrm{d} .015^{*}$ & 1.639 & $.038^{* * *}$ & 3.928 & $-.015 * * *$ & -3.053 & $-.015^{*}$ & -1.608 \\
\hline Assets maturity & -.030 & -1.206 & -.029 & -1.139 & $-.017 *$ & -1.301 & $185^{* * *}$ & 7.390 \\
\hline Corporate scale & -.008 & -1.399 & $.024 * * *$ & 4.155 & $.015^{* * *}$ & 5.000 & $.018^{* * *}$ & 3.128 \\
\hline Debt scale & $.161 * * *$ & 7.726 & $.160^{* * *}$ & 7.434 & -.007 & -.658 & $.278^{* * *}$ & 13.100 \\
\hline Adjusted R2 & .142 & & .187 & & .077 & & .336 & \\
\hline $\mathrm{F}$ & $14.754^{* *}$ & & $19.991 * * *$ & & $7.953^{* * *}$ & & $42.901 *$ & \\
\hline Sample & 498 & & 498 & & 498 & & 498 & \\
\hline
\end{tabular}

